\title{
An Indigenous Virulent Strain of Erwinia amylovora Lacking the Ubiquitous Plasmid pEA29
}

\author{
Pablo Llop, Victoria Donat, Margarita Rodríguez, Jordi Cabrefiga, Lídia Ruz, \\ José Luis Palomo, Emilio Montesinos, and María M. López
}

First, second, and eighth authors: Departamento de Protección Vegetal y Biotecnología, Instituto Valenciano de Investigaciones Agrarias (IVIA), 46113, Moncada, (Valencia), Spain; third author: Departamento de Biología Celular, Universidad Simón Bolívar, Caracas, Venezuela; fourth, fifth, and seventh authors: Instituto de Tecnología Agroalimentaria, Universidad de Girona, 17071 Girona, Spain; and sixth author: Centro Regional de Diagnóstico, 37080 Salamanca, Spain.

Accepted for publication 29 March 2006.

\begin{abstract}
Llop, P., Donat, V., Rodríguez, M., Cabrefiga, J., Ruz, L., Palomo, J. L., Montesinos, E., and López, M. M. 2006. An indigenous virulent strain of Erwinia amylovora lacking the ubiquitous plasmid pEA29. Phytopathology 96:900-907.

An atypical strain of Erwinia amylovora was isolated near an outbreak of fire blight at a nursery in Spain in 1996. It was obtained from a Crataegus plant showing typical symptoms and was identified as E. amylovora by biochemical tests and enrichment-enzyme-linked immunosorbent assay, but not by polymerase chain reaction using primers based on the pEA29 sequence. Nevertheless, with primers from chromosomal

carries one plasmid of $\approx 70 \mathrm{~kb}$, with no homology with the 29 -kb plasmid common to all pathogenic strains, or with a large plasmid present in some E. amylovora strains. Growth of the strain in minimal medium without thiamine was slower compared with cultures in the same medium with thiamine, a characteristic typical of strains cured of the 29-kb plasmid. Nevertheless, aggressiveness assays on pear, apple, and Pyracantha plants and in immature pear fruit showed that this strain exhibited a virulence level similar to other strains containing pEA29. To the best of our knowledge, this is the first report of the isolation from naturally infected plant material of a pathogenic strain of $E$. amylovora without pEA29, but with a plasmid of $\approx 70 \mathrm{~kb}$ not previously described.
\end{abstract} regions, the isolate gave the expected amplification band. This strain
Erwinia amylovora is the causal agent of fire blight, a disease that causes severe losses on rosaceous crops as pear and apple and ornamental plants such as Pyracantha, Crataegus, Sorbus, and Cotoneaster spp. (8). The spread of the disease has been important all over the world and, particularly in recent years, in Europe (49). Consequently, there has been a growing concern about eradication measures and detection techniques to reduce the dissemination of the pathogen. Since the discovery of fire blight, intensive research has focused on the epidemiology and control of the disease $(24,40,48)$ and the molecular biology of the genes involved in pathogenicity, virulence, and development of symptoms $(2,11,15,28,44)$. Furthermore, other studies about the phenotypic and genotypic characteristics of the bacterium have shown that this species presents a considerable homogeneity at genetic level $(25,42)$. This genetic homogeneity positively correlates with biological and biochemical similarity and with a broad host range within the family Rosaceae. The only exception is represented by the E. amylovora isolates from Rubus spp., which affect only this genus and not the subfamily Maloideae (46). In addition, all the pathogenic strains isolated from nature and analyzed so far share the presence of a 29-kb plasmid called pEA29. To date, no one has demonstrated conclusively the existence of indigenous isolates of E. amylovora without pEA29. Therefore, it has been assumed that all the pathogenic E. amylovora strains should carry the plasmid pEA29, due to its high stability and nontransmissibility. Because of these characteristics, some studies have focused on the putative role of pEA29 by curing this plasmid from different strains $(17,29,37)$ and studying the subsequent mutant

Corresponding author: M. M. López; E-mail address: mlopez@ivia.es

DOI: 10.1094/PHYTO-96-0900

(c) 2006 The American Phytopathological Society strain behavior. Strains cured of the plasmid showed a decrease in the virulence properties (delayed appearance of symptoms, reduction in the severity of symptoms, and decreased amounts of ooze in artificial inoculations) compared with wild-type strains $(17,29$, 37). Accordingly, involvement of pEA29 in fitness and virulence properties has been proposed.

Fire blight was detected in Spain in 1995 and, since then, our laboratory, which is the Reference Laboratory for plant-pathogenic bacteria, has analyzed most of the isolates representative of the different outbreaks that have occurred until now. More than 1,000 analyses from different fire blight hosts have been performed, and almost 300 isolates of E. amylovora with standard characteristics have been identified. In one survey performed in 1996 at a nursery and vicinities in Segovia, in central Spain, typical symptoms of fire blight were found in different ornamental plants from which E. amylovora was isolated. A detailed analysis of one strain (IVIA1614-2a) obtained from a Crataegus sp. $45 \mathrm{~km}$ from the nursery showed that it lacked the plasmid pEA29.

The objective of the present work was to perform an extensive phenotypic and molecular characterization of the strain, including plasmid profiles and DNA hybridization analyses. The results obtained are related to pathogenicity and virulence on several host plants, and were compared with those of strains of E. amylovora harboring the plasmid pEA29 and with a strain cured of it.

\section{MATERIALS AND METHODS}

Bacterial strains and cultural properties. The bacterial strains employed in the analyses are listed in Table 1. Strain IVIA1614-2a was isolated using a standard protocol (1) from a shoot of a Crataegus plant with fire blight symptoms. All the strains were grown on King's B medium (26), and incubated for 24 to $48 \mathrm{~h}$ at $26^{\circ} \mathrm{C}$. Growth rate in King's B, sucrose nutrient agar 
(SNA) (7), and CCT media (cycloheximide [50 $\mu \mathrm{g} / \mathrm{liter}$, crystal violet $[0.1 \%]$, and thallium nitrate $[1 \%, \mathrm{wt} / \mathrm{vol}])(22)$, as well as minimal medium M9 with glucose as carbon source $(10 \mathrm{ml}$ of a $20 \%$ solution per liter) and with and without thiamine (36), was compared with reference strains in two independent experiments using the Bioscreen C system (Labsystems Oy, Finland). Suspensions of $10 \mu \mathrm{l}$ of $10^{4} \mathrm{CFU} / \mathrm{ml}$ of each strain added to $340 \mu \mathrm{l}$ of each media were incubated at $26^{\circ} \mathrm{C}$ with $10 \mathrm{~s}$ of shaking every $10 \mathrm{~min}$, and the optical density at $600 \mathrm{~nm}$ was recorded for 5 days at intervals of $1 \mathrm{~h}$. Growth morphology on King's B, SNA, CCT, and M9 with and without thiamine and on the selective media $\mathrm{MM} 1 \mathrm{Cu}$ and $\mathrm{MM} 2 \mathrm{Cu}$ (4) and MS with mannitol (10 g/liter) as carbon source (41) were analyzed and compared among the reference strains.

Phenotypic characterization. Biochemical and serological characteristics of strain IVIA1614-2a were compared against some E. amylovora reference strains from different origins and hosts to confirm the identity of the isolate as belonging to such species. The strains were analyzed using biochemical tests, including commercial strips as API50CH, API20E, API20NE, and APIZYM, (BioMérieux, France) following the manufacturer's instructions with modifications (13), and also by their fatty acid profile (50). Enrichment-enzyme-linked immunosorbent assay (ELISA) with specific monoclonal antibodies according to Gorris et al. (19) also was used for identification of the isolate.

Resistance to antibiotics was tested on LB medium (36) supplemented with streptomycin (Str, $50 \mu \mathrm{g} / \mathrm{ml}$ ), kanamycin, ( $\mathrm{Km}$, $50 \mu \mathrm{g} / \mathrm{ml}$ ), kasugamycin (Ksm, $200 \mu \mathrm{g} / \mathrm{ml}$ ), and chloramphenicol $(\mathrm{Cm}, 50 \mu \mathrm{g} / \mathrm{ml})$, and incubated at $26^{\circ} \mathrm{C}$ for $48 \mathrm{~h}$. Other analyses performed involved hypersensitivity reaction (HR) in tobacco leaves (Nicotiana tabacum). The test was performed by infiltrating leaves with bacterial suspensions at $10^{9} \mathrm{CFU} / \mathrm{ml}$ in sterile distilled water and monitoring the HR reaction after $24 \mathrm{~h}$ of incubation at room temperature.

Molecular characterization. Strain IVIA1614-2a was analyzed by different molecular techniques in order to find genetic differences in comparison to reference strains. These techniques included Rep-polymerase chain reaction (PCR) (REP, BOX, and ERIC) (33), pulsed-field gel electrophoresis (PFGE) on total DNA restricted with enzyme $X b a I$ following the method described in Jock et al. (23), and PCR ribotyping with primers from 16S-23S rDNA intergenic spacer as described in McManus and Jones (39). PCR with three sets of chromosomal primers from the works of Bereswill et al. (amsBL and amsBR) (3), Guilford et al. (pEa71pEa72) (21), and Maes et al. (EaF-EaR) (35) was performed in $1 \times$ reaction buffer, $1.5 \mathrm{mM} \mathrm{MgCl}, 100 \mu \mathrm{M}$ dNTPs, and 5 pmols of each primer. The amplification conditions for each primer pair were as described by the authors.
Plasmid and hybridization analyses. The method of Zhou et al. (51) was employed to check the plasmid content of the different strains. The Maxiprep GFII reagent kit (Q-BIOgene) was used to extract the plasmids for subsequent restriction analyses. Restriction profiles with either BamHI or EcoRI of plasmids from reference strains and IVIA1614-2a were compared (BamHI has a unique restriction site in pEA29) (16). The plasmid size was calculated with the fragments obtained with enzyme BamHI using the Kodak digital science 1D software (version 3.0.1; Kodak, New Haven, CT). Plasmids pEA29 from strain CFBP 1430 and the 70-kb plasmid from strain IVIA1614-2a were excised from gel, purified using the Geneclean Turbo kit (Qbiogene), and labeled using the DIG High Prime DNA labeling kit I (Roche, Mannheim, Germany) to be used as probes. The plasmid extractions and restriction digests were transferred onto nitrocellulose membranes and hybridized at $65^{\circ} \mathrm{C}$. The $70-\mathrm{kb}$ probe was stripped off the membrane according to manufacturer's instructions (Roche) to be further hybridized with the pEA29 probe. Plasmids of strain IVIA1614-2a and reference strains were hybridized against the probes before and after restriction with the two enzymes. In addition, total DNA was extracted following a simple protocol (31), digested with EcoRI, and hybridized against the pEA29 probe to detect any homology in the sequence of the chromosome of strain IVIA1614-2a with the pEA29. The detection was performed using the Dig Wash and Block buffer set (Roche) and the membranes developed using X-OMAT UV film (Kodak, France) or, alternatively, visualized using the LAS 3000 system (Fuji Film, Japan).

Incompatibility of the 70-kb plasmid with pEA29 was studied by introduction by electroporation of a plasmid with resistance to kanamycin (27) with the origin of replication of pEA29 into the strain IVIA1614-2a and further analysis of the plasmid content. The vector (pBBR1MCS-2) and the plamid pEA29 were digested with $E c o$ RI and the fragments of the 29-kb plasmid ligated with the vector. The fragment containing the repA gene was employed to transform the IVIA1614-2a strain and to observe whether both plasmids co-existed after repeated culturing. To attempt to determine the incompatibility group of the $70-\mathrm{kb}$ plasmid, several assays were performed by PCR using the primers described in Götz et al. (20) for the groups Inc N (kikA 1-2), Inc P (trfA2 1-2 and kor A 1-2), Inc Q (ori V 1-2), and Inc W (ori T 1-2), including appropriate positive controls, and following the authors' recommendations.

Aggressiveness assays. Aggressiveness assays were performed with strain IVIA1614-2a and reference strains on pear (cv. Conference) and apple (cv. Fuji) plants and on immature pear fruit (cv. Passe Crassane). Self-rooted plants obtained by micropropagation were inoculated by dipping scissors in a $10^{8} \mathrm{CFU} / \mathrm{ml}$ sus-

TABLE 1. Molecular characterization of strain IVIA1614-2a compared with Erwinia amylovora reference strains

\begin{tabular}{|c|c|c|c|c|c|c|c|c|}
\hline \multirow[b]{2}{*}{ Strain } & \multirow[b]{2}{*}{ Origin } & \multirow[b]{2}{*}{ Host } & \multicolumn{3}{|c|}{ Polymerase chain reaction } & \multirow[b]{2}{*}{$\mathrm{PFGE}^{\mathrm{x}}$} & \multirow[b]{2}{*}{ Sourcey } & \multirow[b]{2}{*}{ Reference } \\
\hline & & & pEA29u & Chromosome $^{\mathrm{v}}$ & Ribotypingw $^{\mathrm{w}}$ & & & \\
\hline CFBP1430 & France & Crataegus & + & + & Type 1 & Pt3A & CFBP & 29 \\
\hline $\mathrm{Ea} 273$ & United States & Malus & + & + & Type 1 & Pt4 & CUCM & 45 \\
\hline NCPPB311 & Canada & Pyrus & + & + & Type 1 & Pt1 & NCPPB & $\ldots$ \\
\hline NCPPB3159 & The Netherlands & Malus & + & + & Type 1 & Pt1 & NCPPB & $\ldots$ \\
\hline EPS101 & Spain & Pyrus & + & + & Type 1 & $\mathrm{Pt} 4$ & EPS & 12 \\
\hline IVIA1614-2a & Spain & Crataegus & - & + & Type 1 & Pt3 & IVIA & This work \\
\hline PMV6014z & France & $\ldots$ & - & + & Type 1 & ND & PMV & 29 \\
\hline
\end{tabular}

u Using primers designed from the pEA29 $(5,30,38)$.

$\checkmark$ Using primers designed from the chromosome $(3,21,35)$

${ }^{w}$ Assay as described in McManus and Jones (39).

x Pulsed-field gel electrophoresis (PFGE) profiles obtained according to Jock et al. (23); ND = not determined.

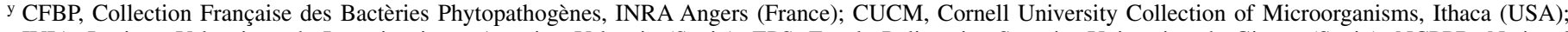
IVIA, Instituto Valenciano de Investigaciones Agrarias, Valencia (Spain); EPS, Escola Politecnica Superior-Universitat de Girona (Spain); NCPPB: National Collection of Plant Pathogenic Bacteria, Central Science Laboratory, York, (UK); PMV, Laboratoire de Pathologie Moleculaire et Végétale, INRA-INA-PG, Paris (France).

z Strain CFBP 1430 cured of plasmid pEA29. 
pension of the bacteria and by cutting the three youngest leaves of the seedlings located at the tip. Plants were covered with plastic bags and maintained in a controlled environment chamber at $22^{\circ} \mathrm{C}$ with high humidity conditions (70 to $90 \%$ relative humidity) under a photoperiod of $16 \mathrm{~h}$ of light. Evaluation of blight symptoms was made after 10 days of incubation by means of a visual scale (from 0 to 4 ). The scale was based on necrosis progression as follows: $0=$ no symptoms, $1=$ necrosis located at the inoculation point and the midvein, $2=$ necrosis affecting the midvein and the petiole, $3=$ necrosis expanding through the shoot, and $4=$ necrosis affecting the shoot and other leaves down in the shoot (14). Disease severity $(S)$ was calculated for each plant according to the following formula:

$$
S=\frac{\sum_{n=1}^{N} I_{n}}{N \times I_{\max }} \times 100
$$

where $I_{n}$ is the corresponding rating of infection in an inoculated leaf, $N$ is the number of leaves inoculated per plant, and $I_{\max }$ is the maximum disease rate.

Aggressiveness assays on immature pear fruit were performed as described previously (12). Immature pear fruit 2 to $3 \mathrm{~cm}$ in diameter of cv. Passe Crassane, collected after 6 weeks from fruit set, were washed once with a solution of sodium hypochlorite ( $1 \%$ active chlorine), rinsed twice with sterile distilled water for $5 \mathrm{~min}$, and allowed to stand to remove excess wetness. Then, fruits were wounded in the equatorial zone (four wounds per fruit) with a flame-sterilized nail to a uniform depth of $5 \mathrm{~mm}$ and approximate width of $3 \mathrm{~mm}$. Each wound was inoculated by deposition of $10 \mu \mathrm{l}$ of a suspension adjusted to $10^{3} \mathrm{CFU} / \mathrm{ml}$. Then, fruits were placed in polystyrene tray packs, covered with plastic bags to maintain high humidity conditions, and incubated at $21^{\circ} \mathrm{C}$. Wounds were considered as infected when either drops of bacterial exudates or necrosis appeared in and around the inoculation site.

The incidence of infected wounds (percent) for each repetition was assessed after 2, 3, 5, 6, 8, and 13 days of incubation.

The experimental design in plant assays consisted of three replicates of three plants with two to three shoots per treatment. In the fruit assay, three replicates of eight fruits with four wounds per fruit were performed, and each wound was analyzed independently, so that 96 evaluation points were made for each treatment. The effect of strain on severity and incidence of infections was determined by an analysis of variance (ANOVA) using the general linear model (GLM) procedure of the statistical analysis system (SAS) (version 8.2; SAS Institute Inc., Cary, NC). Means were separated by the Tukey's test. The aggressiveness assays were repeated twice.

\section{RESULTS}

Phenotypic and molecular characterization and growth rates. The strain IVIA1614-2a was identified as E. amylovora by characterization with API systems, fatty acid profile, and ELISA with specific monoclonal antibodies. It did not show resistance against any of the antibiotics assayed. Hypersensitivity reaction on tobacco leaves was positive for strain IVIA1614-2a as well as for the reference strains. The results obtained in the different assays performed for molecular characterization of the isolate are shown in Table 1 . When analyzed by PCR with primers from the pEA29 plasmid, strain IVIA1614-2a and PMV6014 did not produce a signal. With primers designed for detection of chromosomal DNA, the same band size as the E. amylovora reference strains was obtained. Molecular analyses employed for characterization (REP, ERIC, and BOX) showed identical patterns between IVIA1614-2a and strains carrying plasmid pEA29 (data not shown). Strain IVIA1614-2a exhibited pattern Pt3 by PFGE analysis with restriction enzyme $X b a \mathrm{I}$. This pattern corresponds to isolates obtained from Northern France and Belgium, whereas pattern Pt1 is assigned to isolates from central Europe, pattern Pt2 to eastern Mediterranean regions, and Pt4 to western France and other areas. PCR ribotyping provided the same pattern band for strain IVIA1614-2a and strains corresponding to ribotype 1 as described by McManus and Jones (39).

All the analyses performed with strain IVIA1614-2a provided similar results to reference strains harboring the plasmid pEA29. The morphology of this isolate on King's B, SNA, and CCT media was identical to that of reference E. amylovora strains; however, on MS medium its colonies showed a rough instead of smooth surface. E. amylovora strains do not grow on $\mathrm{MM} 1 \mathrm{Cu}$ medium, and the same was observed with the strain under study. On M9 medium without thiamine, the morphology of strain IVIA1614-2a was identical to that of the strain PMV6014 cured of pEA29, showing small colonies and without production of exopolysaccharide. Growth rate was the same for all the strains compared in all media except in M9 without thiamine. In this medium, PMV6014 and IVIA1614-2a had a similar growth rate, which was slower than that of reference strains which had pEA29 (Fig. 1).

Plasmid profiles and hybridization analyses. The plasmid content of strain IVIA1614-2a was compared with that of reference strains. Plasmid PJB4JI (90 kb) (6) and plasmids from Escherichia coli V517 strain (34) were employed as molecular size standards. Strain IVIA1614-2a harbors only one plasmid of larger size than pEA29, apparently similar to another plasmid present in some of the reference strains employed in this work (Fig. 2A). The band profiles after restriction with enzymes EcoRI and BamHI were different with strain IVIA1614-2a compared with the reference strains (data not shown). It is named pEI70 because the calculation of the band sizes provided an estimate size of $\approx 70 \mathrm{~kb}$ (Fig. 2B). The restriction of the large plasmids present in some of the reference strains (Ea273 and NCPPB311) also showed a band profile different than that of the plasmid from strain IVIA1614-2a (data not shown).

Hybridizations performed after restriction of plasmid content with EcoRI and BamHI enzymes with the 70-kb plasmid from strain IVIA1614-2a as probe were negative with the reference strains, and only such strain produced a hybridization signal (Fig. 3A). With pEA29 as probe, all the reference strains tested hybridized; however, strain IVIA1614-2a did not provide any signal (Fig. 3B). The results obtained with total DNA showed that no homologous sequence belonging to pEA29 was present in the chromosome of strain IVIA1614-2a (data not shown). All these analyses demonstrated, along with the negative results of the PCR assays with primers specific for pEA29 and the analysis of the plasmid content, that this isolate does not harbor the plasmid pEA29 characteristic of all wild Erwinia amylovora strains described. In addition, these results showed that sequences from pEA29 were found in neither the chromosome nor the 70-kb plasmid.

The analysis of the plasmid content of the strain IVIA1614-2a transformed with the plasmid carrying the replication origin of pEA29 showed that both plasmids co-exist and are maintained after repeated culturing on King's B medium supplemented with $\mathrm{Km}$, which demonstrates that pEI70 is compatible with pEA29. The analyses performed to identify the incompatibility group of the large plasmid did not provide positive results with the primers assayed (data not shown).

Aggressiveness assays. Severity of infections and incidence of infected wounds developed by isolate IVIA1614-2a on apple and pear plants and immature pear fruit were compared with those of strains with or without pEA29 (Table 2). Strain IVIA1614-2a exhibited aggressiveness similar to most of the reference strains with pEA29. The values of severity and incidence of infections of strain IVIA1614-2a were similar or below that of Ea273, EPS101, NCPPB3159, and CFBP1430, depending on the host and assay performed. Additionally, strain IVIA1614-2a exhibited similar 
(apple plant assays) or higher aggressiveness (pear plant and immature fruit assays) than the pEA29-cured strain, PMV6014. Ooze production in immature fruit was observed at the same time for all the strains, with exception only of strain NCPPB311, which produced no symptoms or very small necrosis, without ooze production (data not shown). Significant differences in aggressiveness were observed in all assays between this last strain and all the others analyzed.

The time course of incidence of infected wounds in immature pear fruit is shown in Figure 4. Disease development of strain IVIA1614-2a was produced at intermediate levels when compared with the other strains. However, after the thirteenth day from inoculation, no differences in disease levels were observed among strains, with the exception of strain NCPPB311 that showed a much lower level. The time required to observe lesions in wounds was shorter for strain IVIA1614-2a (3 days) than for strains NCPPB3159 and PMV6014 (5 days), and NCPPB311 (8 days).

\section{DISCUSSION}

Several works have demonstrated the presence of plasmid pEA29 in pathogenic strains of E. amylovora $(16,25,29,30,47)$. The lack of both transfer and mobilization genes in pEA29 as judged from its sequence, along with its high stability, has prompted the general idea that all natural virulent strains of E. amylovora should harbor this plasmid.

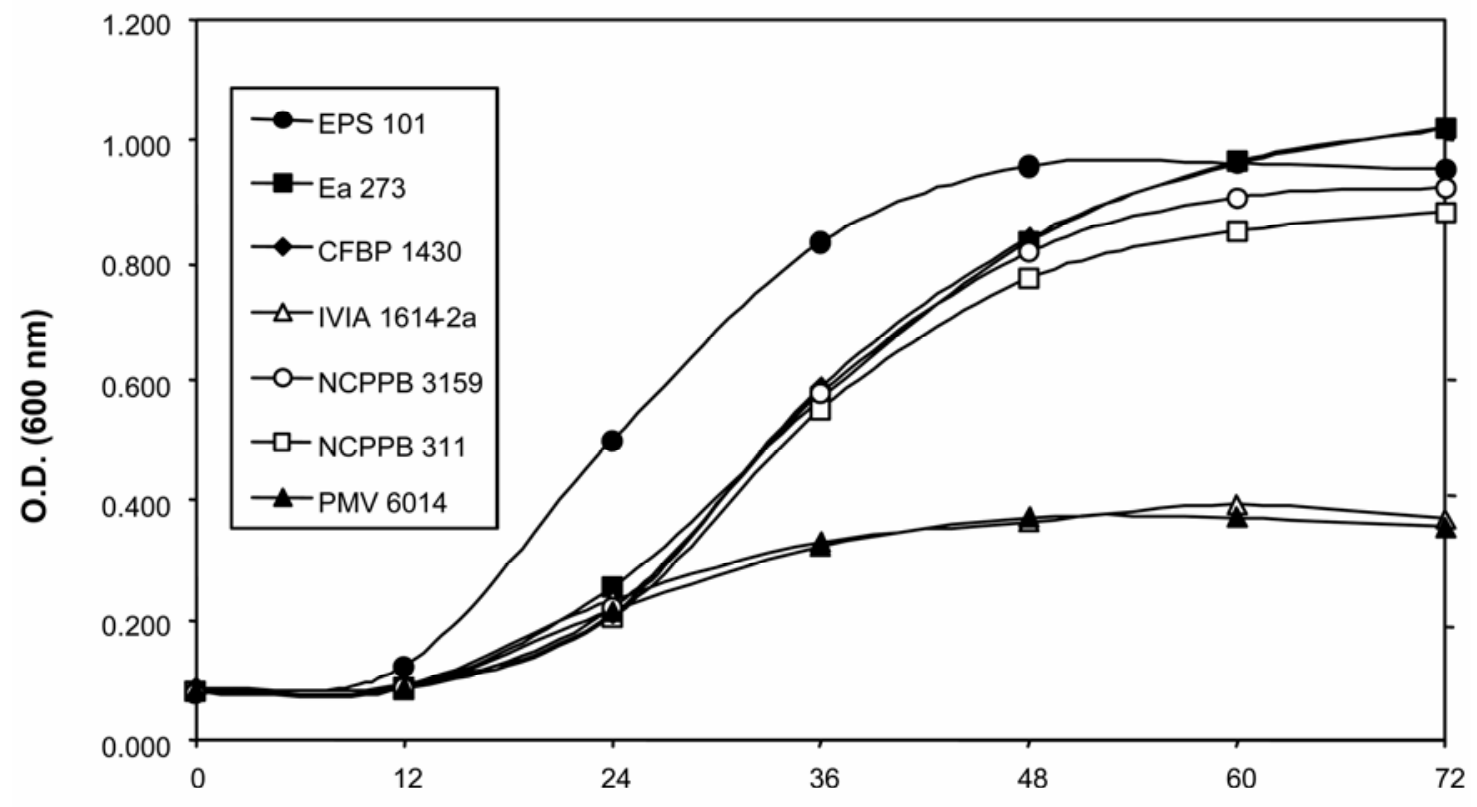

Time (hours)

Fig. 1. Growth of strain IVIA1614-2a compared with reference strains in $\mathrm{M} 9$ minimal medium without thiamine at $26^{\circ} \mathrm{C}$. The experiment was performed three times. The figure shows the results from one representative experiment. The behavior of strain IVIA1614-2a was similar to the cured strain PMV6014. O.D. = optical density.

A

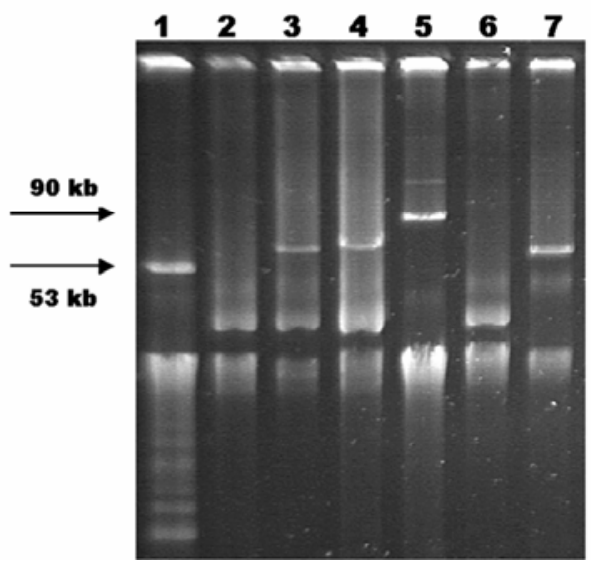

$70 \mathbf{~ k b}$

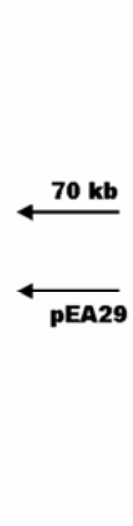

B

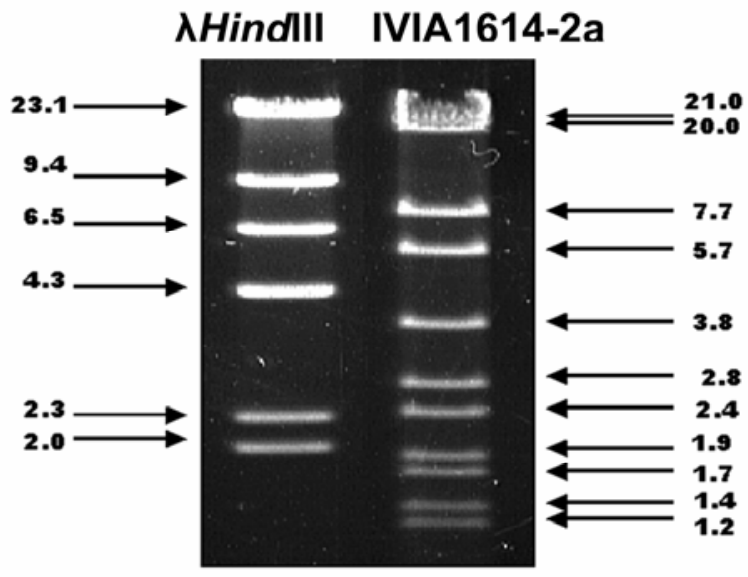

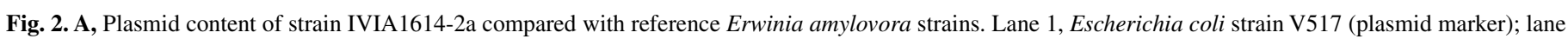

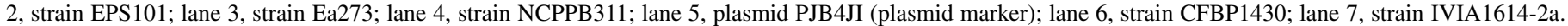

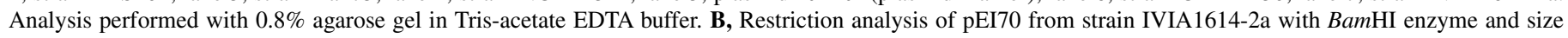
estimation using the Kodak digital science software (v. 3.0.1). The size of the bands obtained is shown in kilobases. The size of the plasmid was approx $70 \mathrm{~kb}$. 
Known pathogenicity or virulence genes have not been found in the sequence of this plasmid and a number of aggressiveness experiments have shown a loss in the virulence properties of E. amylovora strains cured of pEA29 with respect to the same strains harboring the plasmid. This observation led to the conclusion that pEA29 may play a role in aggressiveness and fitness $(17,29,37)$. Nevertheless, pEA29 has been implicated only in the metabolism of thiamine biosynthesis and it has been suggested that this capacity may play a role in fitness of the pathogen in plant tissues. This rationale was used to explain the delay in the development of symptoms in the cured strains and the failure in finding strains without pEA29 in nature. However, some studies have suggested the possible existence of naturally occurring strains that did not carry pEA29. For example, Brown et al. (10) reported that 5 of 100 strains analyzed by PCR for the presence of the plasmid failed to amplify with primers of pEA29. More recently, Brennan et al. (9) analyzed 75 E. amylovora strains with primers for the pEA29 and amplicons were not detected from four isolates. Nevertheless, additional molecular or biochemical analyses to verify the lack of pEA29 in such samples were not performed. Thus, the existence in nature of pathogenic strains without the pEA29 has been suggested but not demonstrated prior to our study.

The isolate IVIA1614-2a is identified as an E. amylovora strain with regard to its biochemical, serological, and molecular characteristics. Concerning its rough morphology on MS medium (41), when 130 E. amylovora strains were assayed for growth on this medium, only 6 of them (5\%) showed rough colonies (13). However, all strains were able to produce levan on SNA and CCT media and showed normal mucoid colony morphology on King's $\mathrm{B}$ medium. In addition, these strains were able to produce ooze in inoculated green pear fruit (13). Thus, the rough morphology on MS does not seem to be associated with the absence of pEA29 in E. amylovora or to a lack of exopolysaccharide production.
A

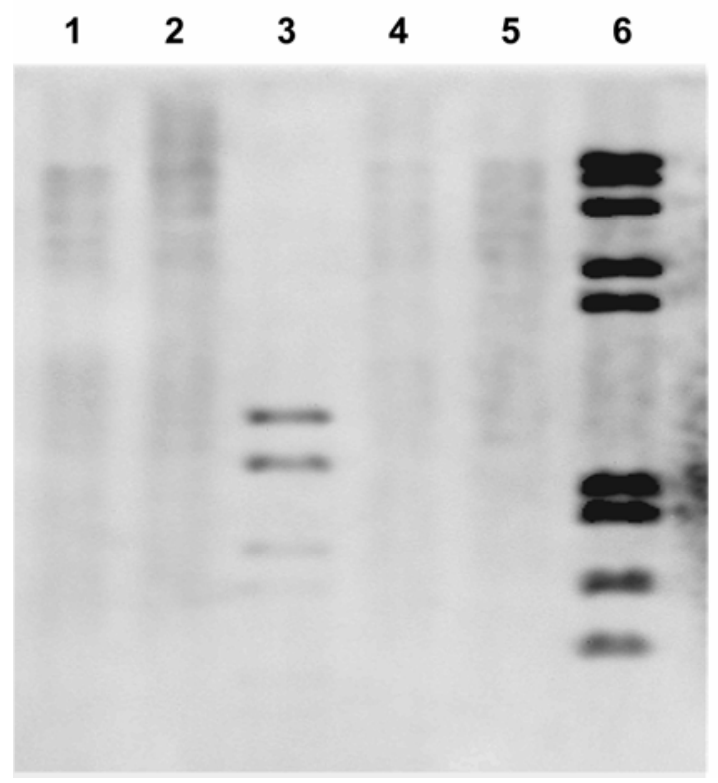

B

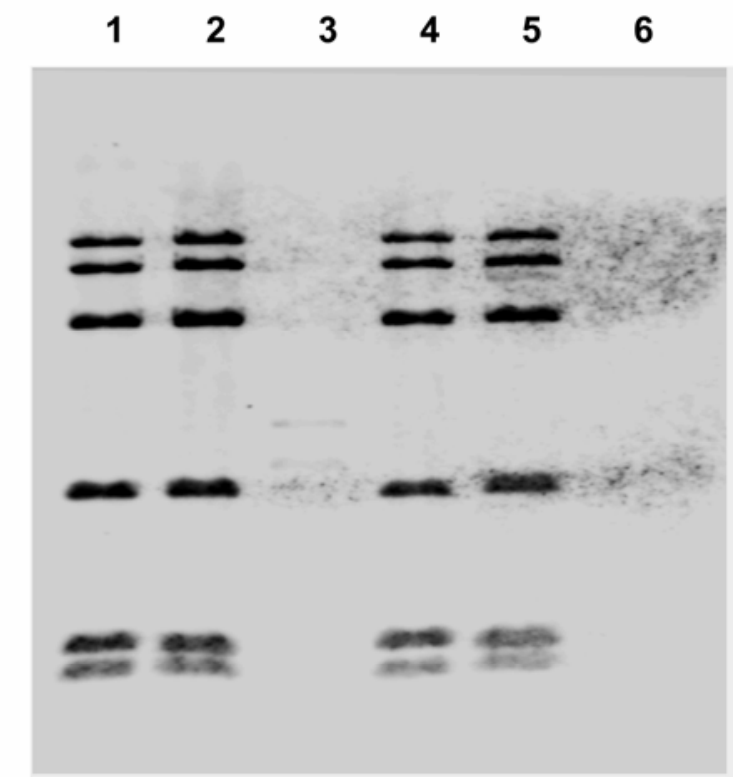

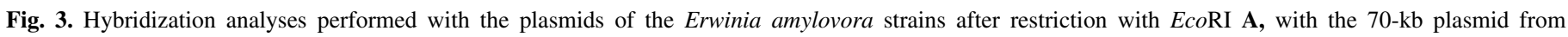

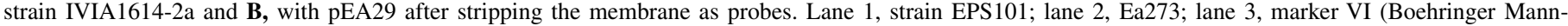

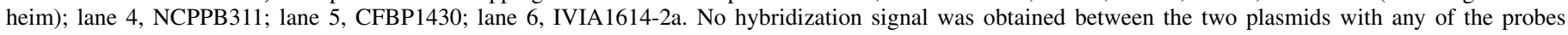
assayed.

TABLE 2. Virulence of strain IVIA 1614-2a in plants and immature pear fruit compared with reference Erwinia amylovora strains ${ }^{\mathrm{X}}$

\begin{tabular}{|c|c|c|c|c|c|c|}
\hline \multirow[b]{3}{*}{ Strain } & \multicolumn{4}{|c|}{ Severity of infections in plants $(\%)^{\mathrm{y}}$} & & \\
\hline & \multicolumn{2}{|c|}{ Pear } & \multicolumn{2}{|c|}{ Apple } & \multicolumn{2}{|c|}{ Incidence of infected wounds $(\%)^{z}$} \\
\hline & Trial 1 & Trial 2 & Trial 1 & Trial 2 & Trial 1 & Trial 2 \\
\hline CFBP1430 & $86.8 \mathrm{a}$ & $87.9 \mathrm{ab}$ & $36.8 \mathrm{ab}$ & $42.2 \mathrm{a}$ & $78.3 \mathrm{ab}$ & $74.4 \mathrm{~b}$ \\
\hline $\mathrm{Ea} 273$ & $60.4 \mathrm{ab}$ & $63.5 \mathrm{~cd}$ & $48.6 \mathrm{ab}$ & $56.1 \mathrm{a}$ & $100.0 \mathrm{a}$ & $100.0 \mathrm{a}$ \\
\hline NCPPB311 & $0.0 \mathrm{~d}$ & $1.0 \mathrm{e}$ & $1.4 \mathrm{c}$ & $0.0 \mathrm{~b}$ & $0.0 \mathrm{~d}$ & $0.0 \mathrm{~d}$ \\
\hline NCPPB3159 & $62.9 \mathrm{ab}$ & $77.4 \mathrm{abc}$ & $53.1 \mathrm{ab}$ & $47.2 \mathrm{a}$ & $56.7 \mathrm{bc}$ & $86.7 \mathrm{ab}$ \\
\hline EPS101 & $81.6 \mathrm{a}$ & $91.7 \mathrm{a}$ & $58.3 \mathrm{a}$ & $65.6 \mathrm{a}$ & $100.0 \mathrm{a}$ & $100.0 \mathrm{a}$ \\
\hline IVIA1614-2a & $66.7 \mathrm{ab}$ & $74.0 \mathrm{bcd}$ & $31.4 \mathrm{~b}$ & $51.0 \mathrm{a}$ & $93.3 \mathrm{a}$ & $94.4 \mathrm{ab}$ \\
\hline PMV6014 & $46.5 \mathrm{c}$ & $58.0 \mathrm{~d}$ & $34.8 \mathrm{ab}$ & $46.6 \mathrm{a}$ & $41.7 \mathrm{c}$ & $25.6 \mathrm{c}$ \\
\hline
\end{tabular}

${ }^{x}$ Means within the same column followed by different letters are significantly different $(P \leq 0.05)$ according to Tukey's test.

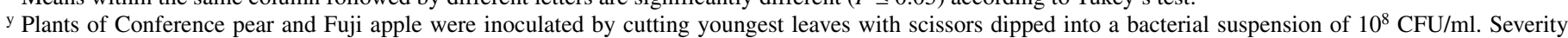
was assessed after 10 days of incubation at $22^{\circ} \mathrm{C}$ and high relative humidity. Severity was calculated as percentage of the maximum observed according to the formula described in Materials and methods. Results are means of three replicates of three plants with two to three shoots per plant.

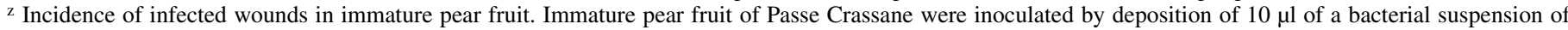
$10^{3} \mathrm{CFU} / \mathrm{ml}$ in each wound. Incidence was assessed after 6 days of incubation at $21^{\circ} \mathrm{C}$ and high relative humidity. Results are means of three replicates of eight fruit with four wounds per fruit. 
Nevertheless, strain IVIA1614-2a showed a rough phenotype, as the mutant PMV6014, whereas the wild strain with the 29-kb plasmid (CFBP1430) did not. Whether this characteristic is related to pEA29 or is specific to the strain is unknown, and analysis with additional strains would be necessary to establish a possible relationship. The growth rate of the strain IVIA1614-2a in several media was similar to that of other E. amylovora strains. IVIA1614-2a presented a slower growth rate only on minimal broth medium without thiamine strain comparable to that shown by PMV6014, the mutant cured of pEA29. Both IVIA1614-2a and PMV6014 had the same colony morphology on M9 medium without thiamine.

Aggressiveness experiments exhibited differential levels among the E. amylovora strains studied, including IVIA1614-2a. Differential virulence has been reported in E. amylovora $(43,47)$ and the effect of strain, cultivar, and plant material has been verified (12). Taking into account the range of aggressiveness among reference E. amylovora strains, strain IVIA1614-2a was intermediate in this characteristic. Mutant PMV6014, a strain cured of pEA29, showed a loss of virulence in the different assays compared with the parental strain, CFBP1430, and our results confirmed those previously reported $(17,29,37)$. In contrast, strain IVIA1614-2a, also lacking the 29-kb plasmid, presented virulence levels similar to wild strain CFBP1430 (Table 2). Mutant PMV6014 without pEA29 was similar to the strain IVIA1614-2a only in apple experiments (Table 2). This may indicate that pEA29 is not essential for aggressiveness in IVIA1614-2a.

Stain IVIA1614-2a does not harbor pEA29, which is characteristic of all pathogenic strains. Furthermore, chromosomal preparations of IVIA1614-2a did not hybridize with pEA29 used as a probe. Nonetheless, strain IVIA1614-2a does have a plasmid of $\approx 70 \mathrm{~kb}$. This plasmid has a size similar to a large plasmid of $56 \mathrm{~kb}$ described in strain Ea273 (47), but with no relationship between them, as demonstrated by the restriction and hybridization analyses. Other large plasmids with sizes similar to the pEI70 have been reported in other E. amylovora strains $(18,29)$; however, the possible association with the plasmid of strain IVIA1614-2a has not been determined. The large plasmid of IVIA1614-2a was compatible with the origin of replication of
pEA29 and, therefore, both plasmids should be maintained in E. amylovora strains. However, the PCR assays performed did not allow us to assign the new plasmid to a known incompatibility group. Nevertheless, it is noteworthy that some of the primers used do not recognize all plasmids from a specific group, and further analyses are necessary to identify the plasmid incompatibility group (20).

Regarding all of the studies carried out on E. amylovora strains, the lack of the 29-kb plasmid represents an uncommon characteristic, and the analyses performed until now have not found, at least in Spain, more strains with this attribute. However, strains without pEA29 able to infect susceptible plants and cause the disease may exist in nature. A wider screening of isolates not analyzed previously by PCR based on the 29-kb plasmid should be performed to evaluate the incidence of strains with no pEA29.

The fact that such strains have not been found previously could be related to (i) the stability of this plasmid, making it very difficult to get rid of; (ii) a reduced fitness for surviving and competing against other strains; or (iii) the low number of studies analyzing large collections of strains by PCR with primers specific to pEA29. In two studies $(9,10)$, several strains that might lack the $29-\mathrm{kb}$ plasmid were reported, but additional research is needed to determine whether they harbor pEA29 or integrated fragments of the plasmid in the chromosomal DNA.

The PCR using primers designed from the 0.9-kb PstI fragment of the pEA29 kb plasmid is considered one of the most sensitive techniques for the detection of E. amylovora $(5,30,38)$. Therefore, the existence of strains without pEA29 compromises these detection systems, an aspect of great concern in epidemiological studies and eradication programs. Furthermore, the detection of these strains strongly supports the need to use a combination of several techniques in an integrated approach for detection of E. amylovora in plant material $(1,32)$.

The existence of a strain of E. amylovora in nature without pEA29 represents a novelty, but probably is not an exception. The origin of this strain remains unclear. Is its $70-\mathrm{kb}$ plasmid involved in virulence features such as those observed in strains with the pEA29? Further studies on the pEI70 and chromosomal content

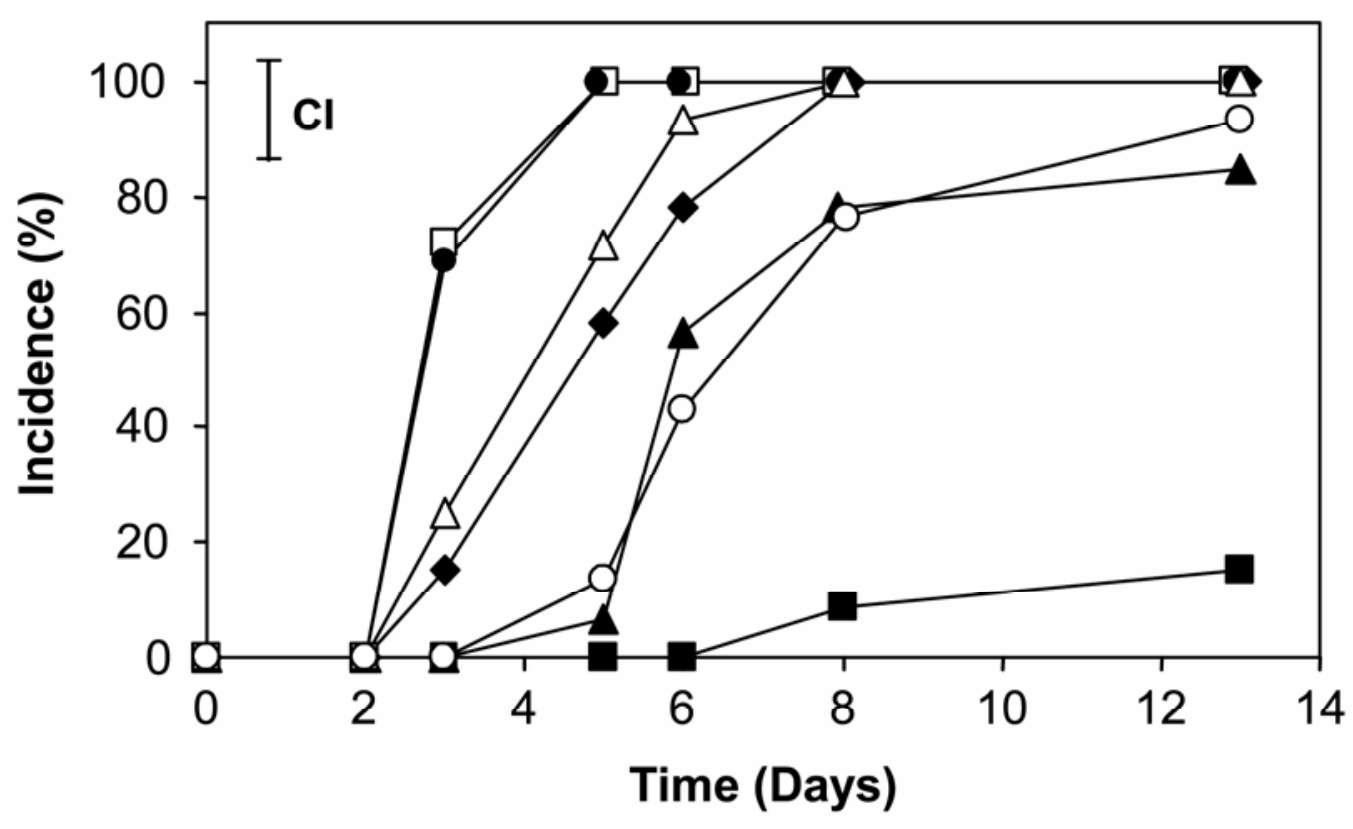

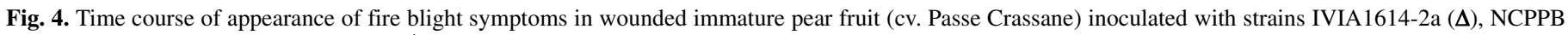

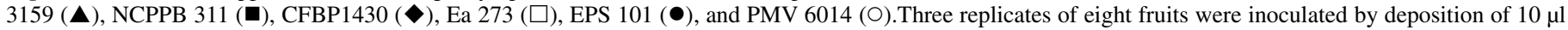

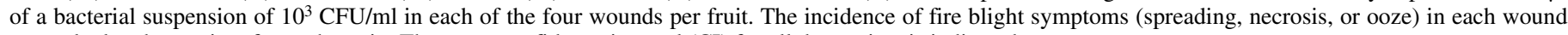
was calculated over time for each strain. The mean confidence interval (CI) for all data points is indicated. 
of strain IVIA1614-2a, compared with those of other E. amylovora strains, will be of great interest to clarify this aspect.

\section{ACKNOWLEDGMENTS}

This work was supported by Projects AGF98-0402-C03 and AGL20012349-C03 from the "Comisión Interministerial de Ciencia y TecnologíaCICYT" of Spain. Victoria Donat thanks the Instituto Valenciano de Investigaciones Agrarias for a predoctoral grant. We thank C. Montón and F. García for fatty acid analyses, M.-A. Barny for providing strain PMV 6014, and O. Esteban for critical reading of the manuscript.

\section{LITERATURE CITED}

1. Anonymous. 2004. Diagnostic protocols for regulated pests. Erwinia amylovora. EPPO Bull. 34:159-171.

2. Barny, M. A., Guinebretière, M. H., Marcais, B., Coissac, E., Paulin, J. P., and Laurent, J. 1990. Cloning of a large gene cluster involved in Erwinia amylovora CFBP1430 virulence. Mol. Microbiol. 4:777-786.

3. Bereswill, S., Bugert, P., Bruchmuller, I., and Geider, K. 1995. Identification of the fire blight pathogen, Erwinia amylovora, by PCR assays with chromosomal DNA. Appl. Environ. Microbiol. 61:26362642.

4. Bereswill, S., Jock, S., Bellemann, P., and Geider, K. 1998. Identification of Erwinia amylovora by growth morphology on agar containing copper sulfate and by capsule staining with lectin. Plant Dis. 82:158-164.

5. Bereswill, S., Pahl, A., Bellemann, P., Zeller, W., and Geider, K. 1992. Sensitive and species-specific detection of Erwinia amylovora by polymerase chain reaction analysis. Appl. Environ. Microbiol. 58:35223526.

6. Beringer, J. E., Beynon, J. L., Buchanan-Wollaston, A. V., and Johnston, A. W. B. 1978. Transfer of drug-resistance transposon Tn5 to Rhizobium. Nature 276:633-635.

7. Billing, E., Baker, L. A. E., Crosse, J. E., and Garret, C. 1961. Characteristics of English isolates of Erwinia amylovora (Burrill) Winslow et al. J. Appl. Bacteriol. 24:195-211.

8. Bonn, W. G., and van der Zwet, T. 2000. Distribution and economic importance of fire blight. Pages 37-55 in: Fire Blight. The Disease and Its Causative Agent, Erwinia amylovora. J. L. Vanneste, ed. CABI Publishing, Wallingford, UK.

9. Brennan, J. M., Doohan, F. M., Egan, D., Scanlan, H., and Hayes, D. 2002. Characterization and differentiation of Irish Erwinia amylovora isolates. J. Phytopathol. 150:414-422.

10. Brown, E. W., Janisiewicz, W., and van der Zwet, T. 1996. Preliminary phenotypic and genetic differentiation of the fire blight bacterium, Erwinia amylovora. Acta Hortic. 411:199-210.

11. Bugert, P., and Geider, K. 1995. Molecular analysis of the ams operon required for exopolysaccharide synthesis of Erwinia amylovora. Mol. Microbiol. 15:917-933.

12. Cabrefiga, J., and Montesinos, E. 2005. Analysis of aggressiveness of Erwinia amylovora using disease-dose and time relationships. Phytopathology 95:1430-1437.

13. Donat, V., Biosca, E., Rico, A., Peñalver, J., Borruel, M., Berra, D., Basterretxea, T., Murillo, J., and López, M. M. 2005. Erwinia amylovora strains from outbreaks of fire blight in Spain: phenotypic characteristics. Ann. Appl. Biol. 146:105-114.

14. Duron, M., Paulin, J. P., and Brisset, M. N. 1987. Use of in vitro propagated plant material for rating fire blight susceptibility. Acta Hortic. 217:317-324.

15. Eastgate, J. A. 2000. Erwinia amylovora: The molecular basis of fire blight disease. Mol. Plant Pathol. 1:325-329.

16. Falkenstein, H., Bellemann, P., Walter, S., Zeller, W., and Geider, K. 1988. Identification of Erwinia amylovora, the fireblight pathogen, by colony hybridization with DNA from plasmid pEA29. Appl. Environ. Microbiol. 54:2798-2802.

17. Falkenstein, H., Zeller, W., and Geider, K. 1989. The 29 kb plasmid, common in strains of Erwinia amylovora, modulates development of fireblight symptoms. J. Gen. Microbiol. 135:2643-2650.

18. Foster, G. C., McGhee, G. C., Jones, A. L., and Sundin, G. W. 2004. Nucleotide sequences, genetic organization, and distribution of pEU30 and pEL60 from Erwinia amylovora. Appl. Environ. Microbiol. 70:75397544

19. Gorris, M. T., Cambra, M., Llop, P., López, M. M., Lecomte, P., Chartier, R., Paulin, J. P., and Bonn, W. G. 1996. A sensitive and specific detection of Erwinia amylovora based on the ELISA-DASI enrichment method with monoclonal antibodies. Acta Hortic. 411:41-46.

20. Götz, A., Pukall, R., Smit, E., Tietze, E., Prager, R., Tschäpe, H., van Elsas, J. D., and Smalla, K. 1996. Detection and characterization of broad-host-range plasmids in environmental bacteria by PCR. Appl. Environ. Microbiol. 62:2621-2628.

21. Guilford, P. J., Taylor, R. K., Clark, R. G., Hale, C. N., Forster, R. L. S., and Bonn, W. G. 1996. PCR-based techniques for the detection of Erwinia amylovora. Acta Hortic. 411:53-56.

22. Ishimaru, C., and Klos, E. J. 1984. New medium for detecting Erwinia amylovora and its use in epidemiological studies. Phytopathology 74:1342-1345.

23. Jock, S., Donat, V., López, M. M., Bazzi, C., and Geider, K. 2002. Following spread of fire blight in Western, Central and Southern Europe by molecular differentiation of Erwinia amylovora strains with PFGE analysis. Environ. Microbiol. 4:106-114.

24. Johnson, K.B., and Stockwell, O. 2000. Biological control of fire blight. Pages 319-337 in: Fire Blight. The Disease and Its Causative Agent, Erwinia amylovora. J. L. Vanneste, ed. CABI Publishing, Wallingford, UK.

25. Kim, J. H., Zumoff, C. H., Tanii, A., Laby, R. J., and Beer, S. V. 1995. Characterization of Erwinia amylovora strains from different hosts and geographical areas. Phytopathology 85:1148.

26. King, E. O., Ward, M. K., and Raney, D. E. 1954. Two simple media for the demonstration of pyocyanin and fluorescein. J. Lab. Clin. Med. 44:301-307.

27. Kovach, M. E., Elzer, P. H., Hill, D. S., Robertson, G. T., Farris, M. A., Roop, R. M., and Peterson, K. M. 1995. Four new derivatives of the broad-host-range cloning vector pBBR1MCS, carrying different antibiotic-resistance cassettes. Gene166:175-176.

28. Laby, R. J., and Beer, S. V. 1992. Hybridization and functional complementation of the hrp gene cluster from Erwinia amylovora strain Ea 321 with DNA of the other bacteria. Mol. Plant-Microbe Interact. 5:412-419.

29. Laurent, J., Barny, M. A., Kotoujansky, A., Dufriche, P., and Vanneste, J. L. 1989. Characterization of a ubiquitous plasmid in Erwinia amylovora. Mol. Plant-Microbe Interact. 2:160-164.

30. Llop, P., Bonaterra, A., Peñalver, J., and López, M. M. 2000. Development of a highly sensitive nested-PCR procedure using a single closed tube for detection of Erwinia amylovora in asymptomatic plant material. Appl. Environ. Microbiol. 66:2071-2078.

31. Llop, P., Caruso, P., Cubero, J., Morente, C., and López, M. M. 1999. A simple extraction procedure for efficient routine detection of pathogenic bacteria in plant material by polymerase chain reaction. J. Microbiol. Methods 37:23-31

32. López, M. M., Keck, M., Llop, P., Gorris, M. T., Peñalver, J., Donat, V., and Cambra, M. 2004. Diagnostic protocols for organisms harmful to plants. Diagnosis on Erwinia amylovora. EPPO. Online publication.

33. Louws, F. J., Fulbright, D. W., Stephens, C. T., and deBruijn, F. J. 1994. Specific genomic fingerprints of phytopathogenic Xanthomonas and Pseudomonas pathovars and strains generated with repetitive sequences and PCR. Appl. Environ. Microbiol. 60:2286-2295.

34. Macrina, F. L., Kopecko, D. J., Jones, K. R., Ayers, D. J., and McCowen, S. M. 1978. A multiple plasmid-containing Escherichia coli strain: Convenient source of size reference plasmid molecules. Plasmid 1:417420 .

35. Maes, M., Garbeva, P., and Crepel, C. 1996. Identification and sensitive endophytic detection of the fire blight pathogen Erwinia amylovora with 23S ribosomal DNA sequences and the polymerase chain reaction. Plant Pathol. 45:1139-1149.

36. Maniatis, T., Fritsch, E. F., and Sambrook, J. 1982. Molecular Cloning. Cold Spring Harbor Laboratory, Cold Spring Harbor, NY.

37. McGhee, G. C., and Jones, A. L. 2000. Complete nucleotide sequence of ubiquitous plasmid pEA29 from Erwinia amylovora strain Ea88: Gene organization and intraspecies variation. Appl. Environ. Microbiol. 66:4897-4907.

38. McManus, P. S., and Jones, A. L. 1995. Detection of Erwinia amylovora by nested PCR and PCR-dot-blot and reverse-blot hybridizations. Phytopathology 85:618-623.

39. McManus, P. S., and Jones, A. L. 1995. Genetic fingerprinting of Erwinia amylovora strains isolated from tree-fruit crops and Rubus spp. Phytopathology 85:1547-1553.

40. McManus, P. S., Stockwell, V. O., Sundin, G. W., and Jones, A. L. 2002. Antibiotic use in plant agriculture. Annu. Rev. Phytopathol. 40:443465.

41. Miller, T. D., and Schroth, M. N. 1972. Monitoring the epiphytic population of Erwinia amylovora on pear with a selective medium. Phytopathology 62:1175-1182.

42. Momol, M. T., and Aldwinckle, H. S. 2000. Genetic diversity and host range of Erwinia amylovora. Pages 55-72 in: Fire Blight. The Disease and Its Causative Agent, Erwinia amylovora. J. L. Vanneste, ed. CABI Publishing, Wallingford, UK.

43. Norelli, J. L., Aldwinckle, H. S., and Beer, S. V. 1986. Differentia susceptibility of Malus spp. cultivars Robusta 5, Novole, and Ottawa 523 to Erwinia amylovora. Plant Dis. 70:1017-1019. 
44. Oh, C.-S., and Beer, S. V. 2005. Molecular genetics of Erwinia amylovora involved in the development of fire blight. FEMS Microbiol. Lett. 253:185-192.

45. Seemuller, E. A., and Beer, S. V. 1976. Absence of cell wall polysaccharide degradation by Erwinia amylovora. Phytopathology 66:433-436.

46. Starr, M. P., Cardone, C., and Folsom, D. 1951. Bacterial fire blight of raspberry. Phytopathology 41:915-919.

47. Steinberger, E. M., Cheng, G. Y., and Beer, S. V. 1990. Characterization of a 56-kb plasmid of Erwinia amylovora Ea322: Its noninvolvement in pathogenicity. Plasmid 24:12-24.
48. Thomson, S. V. 2000. Epidemiology of fire blight. Pages 9-36 in: Fire Blight. The Disease and Its Causative Agent, Erwinia amylovora. J. L. Vanneste, ed. CABI Publishing, Wallingford, UK.

49. van der Zwet, T., and Bonn, W. G. 1999. Recent spread and current worldwide distribution of fire blight. Acta Hortic. 489:167-168.

50. van der Zwet, T., and Wells, J. M. 1993. Application of fatty acid class analyses for the detection and identification of Erwinia amylovora. Acta Hortic. 338:233.

51. Zhou, C., Yang, Y., and Jong, A. Y. 1990. Mini-prep in ten minutes. Biotechniques 82:172-173. 